\title{
Analysis of climatic and geographic factors affecting the presence of chytridiomycosis in Australia
}

\author{
A. Drew, E. J. Allen*, L. J. S. Allen \\ Department of Mathematics and Statistics, Texas Tech University, Lubbock, Texas 79409-1042, USA
}

\begin{abstract}
Chytridiomycosis is an emerging fungal disease that has been implicated in the global decline of amphibian populations. Identifying climatic and geographic factors associated with its presence may be useful in control and prevention measures. Factors such as high altitude, cool temperature, and wet climate have been associated with chytridiomycosis outbreaks. Although some of these factors have been studied in a laboratory setting, there have been few studies in a natural setting. In this investigation, the relationship between altitude, average summer maximum temperature, or the amount of rainfall and the presence or absence of chytridiomycosis are statistically tested using data from 56 study sites in Australia. Currently, in Australia, 48 native species of wild amphibians have been found infected with chytridiomycosis. The 56 sites in the present study, extending along approximately $50 \%$ of the coastline of Australia, have been identified as either a chytrid site, where $\geq 1$ species are infected with chytridiomycosis, or a no-decline site, where none of the species present at the site are experiencing a decline or are known to be infected. The odds-ratio test and twoproportions test applied to this data indicate that the presence of chytridiomycosis in Australia is significantly related to temperature. In particular, the presence of chytridiomycosis is more likely at sites where the average summer maximum temperature is $<30^{\circ} \mathrm{C}$. The results of the analyses do not indicate a significant relationship between the presence of chytridiomycosis and altitude or rainfall.
\end{abstract}

KEY WORDS: Chytridiomycosis · Amphibians · Australia · Temperature

\section{INTRODUCTION}

Batrachochytrium dendrobatidis is a fungal pathogen that has been implicated in the global decline of amphibian populations (Berger et al. 1999, Bosch et al. 2001, Daszak et al. 2003). B. dendrobatidis is responsible for the emerging amphibian disease known as chytridiomycosis. Chytridiomycosis was first recorded in the United States in the 1960s, in Australia in the 1970s, in Central America and in South America in the 1980s, and in Europe in the 1990s (Berger et al. 1999, Weldon et al. 2004). The earliest case of an amphibian chytrid infection was recently identified in a 1938 Xenopus laevis frog specimen from southern Africa (Weldon et al. 2004). It appears that chytridiomycosis persisted as a stable endemic infection in southern African amphibians for at least 23 yr before any positive specimen was found outside Africa (Weldon et al. 2004). This suggests that southern Africa may be the source of the amphibian chytrid fungus and that the international trade in $X$. laevis may have facilitated the spread of this pathogen (Weldon et al. 2004).

In experimental settings, Batrachochytrium dendrobatidis does not grow well or grows slowly at temperatures $>28^{\circ} \mathrm{C}$ (Daszak et al. 2003, Piotrowski et al. 2004). When cultures of $B$. dendrobatidis are exposed to $30^{\circ} \mathrm{C}$ for $8 \mathrm{~d}, 50 \%$ of replicates are killed (Piotrowski et al. 2004). In addition, at $37^{\circ} \mathrm{C}$, there is $100 \%$ mortality of the pathogen within $4 \mathrm{~h}$ (Johnson et al. 2003) and frogs Litoria chloris are cleared of infection within $16 \mathrm{~h}$ (Woodhams et al. 2003). In other experimental infections, mortality of amphibians due to chytridiomycosis increases at lower temperatures, with higher mortality rates at $23^{\circ}$ than at $27^{\circ} \mathrm{C}$ (Berger et al. 2004). Infected western toads Bufo boreas in Colorado had high mortality when kept at either $12^{\circ}$ or $23^{\circ} \mathrm{C}$, but survived when kept on a $5^{\circ} / 30^{\circ} \mathrm{C}$ diel temperature schedule for $42 \mathrm{~d}$ (Collins et al. 2003). 
Other geographic and climatic characteristics corresponding to infected sites have been noted, including high altitude and rainforest habitat (Bosch et al. 2001, Collins et al. 2003). Thermal and hydric environments that cycle together may impact the growth of chytridiomycosis (Collins et al. 2003). For example, in an experimental setting, Litoria chloris exposed continuously to mist developed disease faster than animals exposed to either continual rain or dry air with access to water (Collins et al. 2003). In Central America, most amphibian declines occurred above $500 \mathrm{~m}$ in elevation (Young et al. 2001).

These associations between chytridiomycosis and temperature, altitude, or rainfall have been noted primarily in experimental settings. They have not been thoroughly investigated in natural settings. An understanding of the geographic and climatic factors associated with the presence of chytridiomycosis may help in predicting locations particularly susceptible to infection.

Currently, in Australia, 48 native species of wild amphibians from 2 families (Hylidae and Myobatrachidae) have been found infected with chytridiomycosis. These 48 species represent $22 \%$ of the 218 Australian native species. (See: www.jcu.edu.au/school/phtm/PHTM/ frogs/chyspec.htm, R. Speare, L. Berger, Chytridiomycosis in amphibians in Australia, January 26, 2005.) Longitudinal studies conducted in Australia are ongoing (e.g. Retallick et al. 2004). Because of the high level of concern for chytridiomycosis in Australia and other parts of the world, extensive databases have been prepared by several researchers (R. Speare, James Cook University; L. Berger, Amphibian Diseases Network; T. Halliday \& J. Kauffman, Declining Amphibian Population Task Force). In the present investigation, these databases are used to study the association between the presence of chytrid fungus on amphibian populations in Australia and the amount of rainfall, the summer maximum temperature, and the average altitude.

\section{MATERIALS AND METHODS}

Materials. The data used in this investigation are restricted to Australia, where a high level of concern about amphibians has resulted in extensive monitoring activities (Berger et al. 1998). The data involve information from 56 study sites that are located along the east coast of Australia and parts of the south and west coasts. The sites are shown in Fig. 1.

It has been estimated that chytrid fungus may spread at a rate of $>100 \mathrm{~km} \mathrm{yr}^{-1}$ (Alexander \& Eischeid 2001). Because of the rapid rate of spread and the close proximity of study sites where chytridiomycosis is present and where it is not present, it is assumed in this investigation that all of the sites in Fig. 1 have been exposed to chytrid

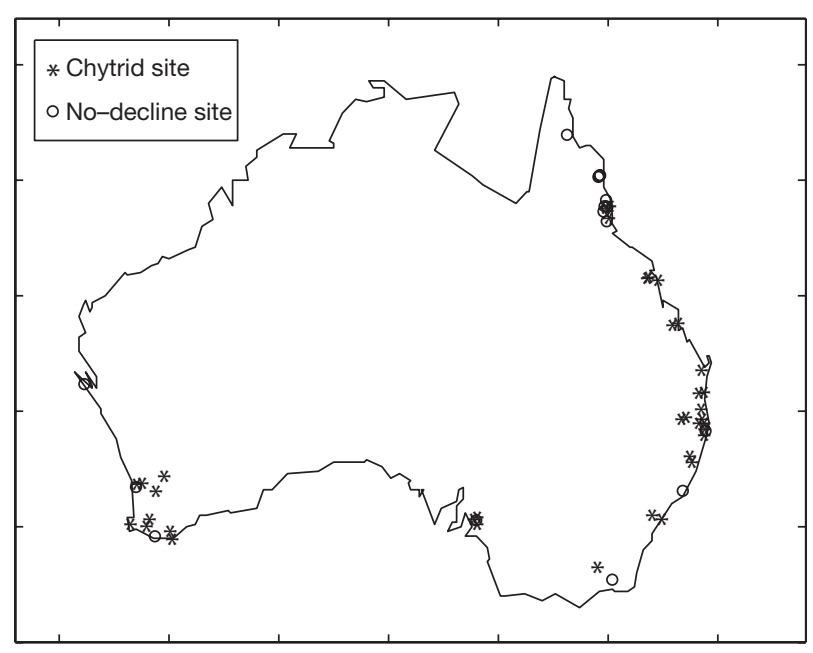

Fig. 1. Sites (56) on the continent of Australia, where either chytridiomycosis (chytrid) has been confirmed in $\geq 1$ amphibian species $(*)$ or where chytridiomycosis has not been reported and it has been observed that $\geq 1$ species have not declined in abundance $(0)$

fungus. Since all of the sites have been exposed to Batrachochytrium dendrobatidis, but not all of the sites are infected, it is hypothesized that there is a relationship between the presence of chytridiomycosis and climate or geographic features of the study site. It must be noted that a few species of amphibians have been found to be resistant to chytridiomycosis (Collins et al. 2003, Daszak et al. 2003). Therefore, it is important that the criteria used for defining a site as free of chytridiomycosis involve observations of several different species.

The data are classified according to the presence or the absence of chytridiomycosis. Sites are classified as Type A, B, or C. Type A sites are the sites where chytridiomycosis is present and has been confirmed in $\geq 1$ amphibian species. It has been noted that after an outbreak of chytridiomycosis has resulted in a population decline, it may still persist in the remnant population as a stable, endemic-level infection (Retallick et al. 2004). (Chytrid infection in animal or tissue samples is detected either by histological examination and electron microscopy, which examine tissue for the presence of zoospores or zoosporangia, or by rtPCR [real-time polymerase chain reaction]). Type $\mathrm{B}$ and $\mathrm{C}$ sites, where chytridiomycosis is absent, are referred to as 'nodecline sites'. These sites are classified as no-decline sites based on the following 3 criteria: (1) amphibian populations have been monitored, (2) chytridiomycosis has not been reported at the site, and ( 3$) \geq 1$ species is known (monitored) to have not declined in abundance, and no other species has been observed to have declined, although their status may be unknown. Additional criteria define these no-decline sites as either Type B or Type C. A no-decline site is referred to as 
Type B if it is known that $\geq 1$ species have not declined in abundance and is referred to as Type $\mathrm{C}$ if $\geq 2$ are known not to have declined. See Table 1 for a list of the criteria defining these sites. Note that Type B and C sites are not mutually exclusive; Type B sites include Type $\mathrm{C}$ sites. Type $\mathrm{C}$ sites, where $\geq 2$ species of amphibians are known to be not in decline, have greater likelihood for the absence of chytridiomycosis than Type B sites. However, it is useful for comparison purposes to study both Type B and Type C sites.

Type A sites are listed in Table 2. The infected sites were identified from reported data that was compiled by R. Speare of James Cook University in Australia and L. Berger of the Amphibian Diseases Network. (See: www.jcu.edu.au/school/phtm/PHTM/frogs/chyspec.htm, Chytridiomycosis in amphibians in Australia, January

Table 1. Amphibian site criteria that define the 3 site types $\mathrm{A}, \mathrm{B}$, and $\mathrm{C}$

\begin{tabular}{|ll|}
\hline $\begin{array}{l}\text { Site } \\
\text { type }\end{array}$ & \multicolumn{1}{c|}{ Criteria } \\
\hline A & Chytridiomycosis recorded at this site \\
B & $\begin{array}{l}\text { (1) Species monitored at this site } \\
\text { (2) Chytridiomycosis not recorded } \\
\text { (3) Number of species known to be in decline }=0\end{array}$ \\
C & $\begin{array}{l}\text { (4) Number of species known to be not in decline } \geq 1 \\
\text { (1) Number of species known to be not in decline } \geq 2\end{array}$ \\
\end{tabular}

26,2005 .) If latitude and longitude information was not available for a study site or if chytrid fungus was found only on captive amphibians, then the site was omitted. Type B and C sites are listed in Table 3. Type B and C sites were identified from the Declining Amphibian Database (T. Halliday \& J. Kauffman unpubl. data), which provided the number of species known to be not in decline at each site, minimum and maximum altitudes for each site, and corresponding longitudes and latitudes. There is an overlap in the representative species from the 2 databases given in Tables $2 \& 3$, indicating that site location is important for chyrid infection.

The temperature and rainfall data were obtained for all sites from maps provided by the Australian Commonwealth Bureau of Meteorology. (See: www.bom. gov.au/climate/averages.) The rainfall and temperature data were based on the 30 yr period from 1961 to 1990 , during much of this period chytrid fungus was spreading across Australia. Altitude, temperature, and rainfall data (A-T-R) are given in Tables $2 \& 3$. Altitude (A) is listed as either 0 or 1 . If the average altitude of the site is $<500 \mathrm{~m}$, the altitude is listed as 0 . If the altitude is listed as 1 , then the average altitude of the site is $>500 \mathrm{~m}$. The temperature $(\mathrm{T})$ is listed as either 0 or 1 . If the temperature is listed as 0 , then the site's average summer maximum temperature is $>30^{\circ} \mathrm{C}$. (That is, the proportion of years that the average summer maximum temperature is $>30^{\circ} \mathrm{C}$ is $>50 \%$. Summer consists of the months of December, January, and February.) If the temperature

Table 2. Location of Type A sites by longitude and latitude and classification by altitude (A), temperature (T), and rainfall (R). For altitude, $0=$ altitude of site is $<500 \mathrm{~m}$ and $1=$ altitude of site is $>500 \mathrm{~m}$. For temperature, $0=$ average summer maximum temperature is $>30^{\circ} \mathrm{C}$ and $1=$ average summer maximum temperature is $<30^{\circ} \mathrm{C}$. For rainfall, $0=$ average October rainfall is $<50 \mathrm{~mm}$ and 1 = average October rainfall is $>50 \mathrm{~mm}$. The data include 6 species from the family Myobatrachidae and 14 species from the family Hylidae

\begin{tabular}{|c|c|c|c|c|c|c|c|c|c|c|c|}
\hline \multirow{2}{*}{$\frac{\text { Site }}{\text { Perth }}$} & \multicolumn{2}{|c|}{ Location } & \multirow{2}{*}{$\frac{A}{0}$} & \multirow{2}{*}{$\frac{\mathrm{T}}{1}$} & \multirow{2}{*}{$\frac{\mathrm{R}}{0}$} & \multirow{2}{*}{$\begin{array}{l}\text { Site } \\
\text { Topaz }\end{array}$} & \multicolumn{2}{|c|}{ Location } & \multirow{2}{*}{$\frac{A}{1}$} & \multirow{2}{*}{$\begin{array}{l}\mathrm{T} \\
1\end{array}$} & \multirow{2}{*}{$\begin{array}{r}\mathrm{R} \\
1\end{array}$} \\
\hline & $115.83^{\circ} \mathrm{E}$ & $31.93^{\circ} \mathrm{S}$ & & & & & $145.72^{\circ} \mathrm{E}$ & $17.42^{\circ} \mathrm{S}$ & & & \\
\hline Boyup Lake & $116.40^{\circ} \mathrm{E}$ & $33.83^{\circ} \mathrm{S}$ & 0 & 1 & 1 & Frenchman & $145.93^{\circ} \mathrm{E}$ & $17.32^{\circ} \mathrm{S}$ & 0 & 1 & 1 \\
\hline Manjimup & $116.15^{\circ} \mathrm{E}$ & $34.23^{\circ} \mathrm{S}$ & 0 & 1 & 1 & Tully & $145.93^{\circ} \mathrm{E}$ & $17.93^{\circ} \mathrm{S}$ & 0 & 1 & 1 \\
\hline Mt. Barker & $117.67^{\circ} \mathrm{E}$ & $34.63^{\circ} \mathrm{S}$ & 0 & 1 & 1 & Casino & $153.05^{\circ} \mathrm{E}$ & $28.87^{\circ} \mathrm{S}$ & 0 & 1 & 1 \\
\hline Mt. Helena & $116.20^{\circ} \mathrm{E}$ & $31.88^{\circ} \mathrm{S}$ & 0 & 0 & 1 & Brisbane & $153.02^{\circ} \mathrm{E}$ & $27.50^{\circ} \mathrm{S}$ & 0 & 1 & 1 \\
\hline Sawyers Valley & $116.20^{\circ} \mathrm{E}$ & $31.90^{\circ} \mathrm{S}$ & 0 & 0 & 1 & Rockhampton & $150.50^{\circ} \mathrm{E}$ & $23.38^{\circ} \mathrm{S}$ & 0 & 0 & 1 \\
\hline Witchcliffe & $115.10^{\circ} \mathrm{E}$ & $34.03^{\circ} \mathrm{S}$ & 0 & 1 & 1 & Mackay & $149.20^{\circ} \mathrm{E}$ & $21.15^{\circ} \mathrm{S}$ & 0 & 1 & 0 \\
\hline Boulder Rock & $117.02^{\circ} \mathrm{E}$ & $32.37^{\circ} \mathrm{S}$ & 0 & 0 & 0 & Alstonville & $153.43^{\circ} \mathrm{E}$ & $28.83^{\circ} \mathrm{S}$ & 0 & 1 & 1 \\
\hline Elleker & $117.73^{\circ} \mathrm{E}$ & $35.09^{\circ} \mathrm{S}$ & 0 & 1 & 1 & Kinka Beach & $150.80^{\circ} \mathrm{E}$ & $23.23^{\circ} \mathrm{S}$ & 0 & 0 & 1 \\
\hline Kellerberin & $117.72^{\circ} \mathrm{E}$ & $31.63^{\circ} \mathrm{S}$ & 0 & 0 & 0 & Maryborough & $152.70^{\circ} \mathrm{E}$ & $25.53^{\circ} \mathrm{S}$ & 0 & 1 & 1 \\
\hline Homebush Bay & $151.22^{\circ} \mathrm{E}$ & $33.88^{\circ} \mathrm{S}$ & 0 & 1 & 1 & Cunningham's Gap & $151.85^{\circ} \mathrm{E}$ & $28.15^{\circ} \mathrm{S}$ & 1 & 1 & 1 \\
\hline Hoskinstown & $149.45^{\circ} \mathrm{E}$ & $35.42^{\circ} \mathrm{S}$ & 1 & 1 & 1 & Eungella NP & $148.48^{\circ} \mathrm{E}$ & $21.13^{\circ} \mathrm{S}$ & 1 & 1 & 1 \\
\hline Bellingen & $152.88^{\circ} \mathrm{E}$ & $30.45^{\circ} \mathrm{S}$ & 0 & 1 & 1 & Goomburra & $152.13^{\circ} \mathrm{E}$ & $28.05^{\circ} \mathrm{S}$ & 1 & 1 & 1 \\
\hline Bowraville & $152.85^{\circ} \mathrm{E}$ & $30.65^{\circ} \mathrm{S}$ & 0 & 1 & 1 & Canungra & $153.17^{\circ} \mathrm{E}$ & $28.03^{\circ} \mathrm{S}$ & 0 & 1 & 1 \\
\hline Dorrigo Plateau & $152.70^{\circ} \mathrm{E}$ & $30.33^{\circ} \mathrm{S}$ & 1 & 1 & 1 & Dalrymple Gap & $148.52^{\circ} \mathrm{E}$ & $21.10^{\circ} \mathrm{S}$ & 1 & 1 & 1 \\
\hline Woodville & $138.55^{\circ} \mathrm{E}$ & $34.88^{\circ} \mathrm{S}$ & 0 & 1 & 1 & Upper Tallebudgera & $153.33^{\circ} \mathrm{E}$ & $28.20^{\circ} \mathrm{S}$ & 0 & 1 & 1 \\
\hline Mt. Compass & $138.62^{\circ} \mathrm{E}$ & $35.37^{\circ} \mathrm{S}$ & 0 & 1 & 1 & Conondales & $152.72^{\circ} \mathrm{E}$ & $26.73^{\circ} \mathrm{S}$ & 0 & 1 & 1 \\
\hline Bogong & $147.22^{\circ} \mathrm{E}$ & $36.80^{\circ} \mathrm{S}$ & 1 & 1 & 1 & Buderim & $153.05^{\circ} \mathrm{E}$ & $26.68^{\circ} \mathrm{S}$ & 0 & 1 & 1 \\
\hline Springwood & $150.55^{\circ} \mathrm{E}$ & $33.70^{\circ} \mathrm{S}$ & 0 & 1 & 1 & Lamington & $153.00^{\circ} \mathrm{E}$ & $28.23^{\circ} \mathrm{S}$ & 0 & 1 & 1 \\
\hline Adelaide & $138.60^{\circ} \mathrm{E}$ & $34.93^{\circ} \mathrm{S}$ & 0 & 1 & 1 & Brindabella Range & $148.73^{\circ} \mathrm{E}$ & $35.40^{\circ} \mathrm{S}$ & 1 & 1 & 1 \\
\hline
\end{tabular}


Table 3. Location of Type B and Type C sites by longitude and latitude and classification by altitude (A), temperature (T), and rainfall (R). NAND: number of amphibian species known to be not in decline. The data include 8 species from the family Myobatrachidae, 7 species from the family Hylidae, 1 species from the family Ranidae, and 1 species from the family Bufonidae. For further details see Table 2

\begin{tabular}{|lcccccc|}
\hline Site & \multicolumn{2}{c}{ Location } & NAND & A & T & R \\
\hline Byron Bay & $153.56^{\circ} \mathrm{E}$ & $28.72^{\circ} \mathrm{S}$ & 1 & 0 & 1 & 1 \\
Eastern Queensland & $145.75^{\circ} \mathrm{E}$ & $17.08^{\circ} \mathrm{S}$ & 1 & 1 & 1 & 1 \\
Bridgewater, & $138.75^{\circ} \mathrm{E}$ & $35.00^{\circ} \mathrm{S}$ & 1 & 0 & 1 & 1 \\
Mt. Lofty Ranges & & & & & & \\
Wallingat State & $152.52^{\circ} \mathrm{E}$ & $32.25^{\circ} \mathrm{S}$ & 2 & 0 & 1 & 1 \\
Forest & & & & & & \\
East Gippsland & $148.35^{\circ} \mathrm{E}$ & $37.50^{\circ} \mathrm{S}$ & 1 & 0 & 1 & 1 \\
Mcllwraith Range & $143.18^{\circ} \mathrm{E}$ & $13.83^{\circ} \mathrm{S}$ & 3 & 1 & 0 & 0 \\
Mt. Misery & $145.22^{\circ} \mathrm{E}$ & $15.90^{\circ} \mathrm{S}$ & 4 & 1 & 0 & 1 \\
Mt. Finnigan (1) & $145.32^{\circ} \mathrm{E}$ & $15.82^{\circ} \mathrm{S}$ & 4 & 0 & 0 & 1 \\
Mt. Finnigan $(2)$ & $145.28^{\circ} \mathrm{E}$ & $15.82^{\circ} \mathrm{S}$ & 4 & 1 & 0 & 1 \\
Topaz & $145.68^{\circ} \mathrm{E}$ & $17.40^{\circ} \mathrm{S}$ & 2 & 1 & 1 & 1 \\
Majuba Creek & $145.85^{\circ} \mathrm{E}$ & $17.43^{\circ} \mathrm{S}$ & 4 & 0 & 1 & 1 \\
Tully Valley & $145.63^{\circ} \mathrm{E}$ & $17.70^{\circ} \mathrm{S}$ & 4 & 0 & 1 & 1 \\
Kirrama & $145.82^{\circ} \mathrm{E}$ & $18.20^{\circ} \mathrm{S}$ & 3 & 0 & 0 & 1 \\
Perth & $115.80^{\circ} \mathrm{E}$ & $32.16^{\circ} \mathrm{S}$ & 1 & 0 & 1 & 1 \\
Shark Bay & $113.31^{\circ} \mathrm{E}$ & $26.33^{\circ} \mathrm{S}$ & 1 & 0 & 0 & 1 \\
Walpole & $116.66^{\circ} \mathrm{E}$ & $34.93^{\circ} \mathrm{S}$ & 1 & 0 & 1 & 1 \\
\hline
\end{tabular}

is listed as 1, then the site's average summer maximum temperature is generally $<30^{\circ} \mathrm{C}$. Rainfall (R) data are for the month of October and are listed as either 0 or 1. If the rainfall is listed as 1 , then the site's October rainfall averages $>50 \mathrm{~mm}$. If the rainfall is listed as 0 , then the site's October rainfall averages $<50 \mathrm{~mm}$. For example, if the A-T-R is 1-0-1, then the altitude of the site is $>500 \mathrm{~m}$, the average summer maximum temperature is $>30^{\circ} \mathrm{C}$, and the average October rainfall is $>50 \mathrm{~mm}$.

In order to study the sensitivity of chytridiomycosis to temperature, the maximum temperature map for the warmest season (summer) was selected and $30^{\circ} \mathrm{C}$ was chosen as an estimate of the maximum temperature for chytrid survival, based on data from the literature (Collins et al. 2003, Daszak et al. 2003, Piotrowski et al. 2004). Note that the map (Fig. 2) of the $30^{\circ} \mathrm{C}$ contour line of the summer maximum temperature (50th percentile) closely follows chytridiomycosis site locations.

In addition, to study the sensitivity of chytridiomycosis to rainfall and altitude, data selections were made. For rainfall, the Australian spring month of October was selected, since amphibians are active in the spring and breeding occurs in the spring for many species. The $50 \mathrm{~mm}$ contour line on the October average rainfall map follows closely the chytridiomycosis site locations (Drew 2004). (Future work could include extending the statistical analyses to other seasonal or annual rainfall data, to precipitation from fog or dew, and to the presence of protected wet microenvironments.) An altitude of $500 \mathrm{~m}$ was chosen as a reasonable estimate for the minimum altitude for chytrid growth based on data from the literature on amphibian population declines (Young et al. 2001).

Methods. Two standard statistical tests are applied to study the significance of altitude, temperature, and rainfall on the presence or absence of chytridiomycosis at site locations. The first statistical test applies a test for the equality of 2 proportions (Dixon \& Massey 1969). The null hypothesis is that the proportion of Type A sites and the proportion of Type B or $\mathrm{C}$ sites are equal and do not depend on the given geographical (altitude) or climatic (rainfall or temperature) feature. The proportions are calculated for each set of data and the $\mathrm{p}$ values are determined. A small p-value for the test indicates that the hypothesis is not valid, thereby implying that Type A sites differ from Type B or C sites with regard to that feature. The second statistical procedure applies the odds-ratio (OR) test (Hosmer \& Lemeshow 1989). In this test, the ratio of 2 odds is calculated, namely, the odds that a geographic or climatic feature is present given that it is a Type A site and the odds that the characteristic is present given that it is a Type $\mathrm{B}$ or $\mathrm{C}$ site. If $O R=1$, then the odds are the same that the characteristic is present at both Type A sites and Type B or $\mathrm{C}$ sites. The null hypothesis asserts that OR $=1$. A $90 \%$ confidence interval for $\mathrm{OR}$ is calculated. If the value unity is not included in the confidence interval, then the null hypothesis can be rejected at the significance level 0.10 , implying that the sites differ with respect to the climatic or geographic feature tested.

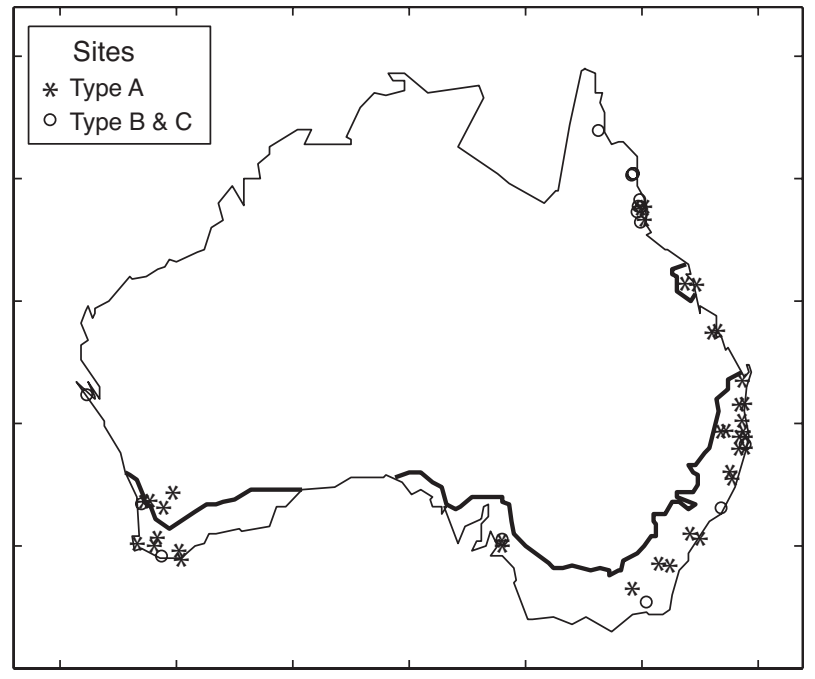

Fig. 2. A contour line for the average summer maximum temperature is plotted against the locations of Type A, B, and $\mathrm{C}$ sites. The contour divides the continent of Australia into 2 regions. North of the contour, for any given year, there is $>50 \%$ probability that the average summer maximum temperature is $>30^{\circ} \mathrm{C}$. South of the contour, for any given year, there is $>50 \%$ probability that the average summer maximum temperature is $<30^{\circ} \mathrm{C}$ 


\section{RESULTS}

\section{Rainfall}

For October rainfall data, in comparing Type A and $\mathrm{C}$ sites, the test for equality of the proportions gives $\mathrm{p}=$ 0.9207. The test based on Type B sites, which includes the data from Type $C$ sites, gives $p=0.6567$. Based on these $\mathrm{p}$-values, it cannot be inferred that Type A sites differ from Type B sites or Type $\mathrm{C}$ sites with respect to average October rainfall. For the odds-ratio test for Type A sites compared to both Type B and C sites, the $90 \%$ confidence interval for the OR contains the value unity, indicating that the null hypothesis cannot be rejected for this test either.

\section{Altitude}

For the altitude data, where the cut-off for the 2 altitude groups is $500 \mathrm{~m}$, the test for equality of 2 proportions yields $p=0.1779$ and $p=0.4945$ when Type $C$ and $\mathrm{B}$ sites are compared to Type A sites, respectively. In addition, the $90 \%$ confidence intervals for OR contain the value unity. Therefore, the null hypothesis cannot be rejected for the altitude data.

\section{Temperature}

In Table 4, the statistical tests are applied to average summer maximum temperature data, whereby the data are divided into 2 groups based on an average summer maximum temperature 50 th percentile of $30^{\circ} \mathrm{C}$. Note that although 6 Type A sites and 5 Type $\mathrm{C}$ sites have average summer maximum temperatures $>30^{\circ} \mathrm{C}$, the proportion of sites with average summer maximum temperatures $>30^{\circ} \mathrm{C}$ is $55.5 \%$ for Type $\mathrm{C}$ sites and only $15.0 \%$ for Type A sites. The test for equality of 2 proportions between Type A and C sites yields $\mathrm{p}=0.0084$. Therefore, the test for independence of temperature at Type A and $\mathrm{C}$ sites indicates that average summer maximum temperatures are different for chytridiomycosis sites and no decline sites. In particular, Type $C$ sites have higher average summer maximum temperatures than Type A sites. Considering the same test for Type B sites, a low value of $p=0.0638$ is obtained, indicating that Type A sites also have lower average summer maximum temperatures than Type B sites. The odds-ratio test shows that an average summer maximum temperature $<30^{\circ} \mathrm{C}$ is about 7 times greater for Type A sites than it is for Type $\mathrm{C}$ sites $(\mathrm{OR}=$
7.083). Furthermore, the $90 \%$ confidence interval does not include $\mathrm{OR}=1$. The odds of an average summer maximum temperature $<30^{\circ} \mathrm{C}$ is 3.4 times more likely at Type A sites than it is for Type B sites, and the $90 \%$ confidence interval does not include the value unity. Thus, it can be asserted with $90 \%$ confidence that the odds are greater for average summer maximum temperatures $<30^{\circ} \mathrm{C}$ at Type A sites than at Type B or C sites.

\section{DISCUSSION}

In the present study, the relationships between cool climate, high altitude, and wet conditions and the presence of chytridiomycosis were statistically tested based on data for Australia's amphibian populations and additional data collected on temperature, altitude, and rainfall. The statistical tests support the hypothesis that a cool climate is an important factor for the presence of chytridiomycosis. With $90 \%$ confidence, it can be asserted that an average summer maximum temperature of $<30^{\circ} \mathrm{C}$ is statistically significant for the presence of chytridiomycosis. However, the tests do not support the hypotheses that rainfall or altitude are statistically significant factors.

The results from this study provide a measure based on temperature that can be used in conjunction with other measures (rainfall, altitude) to identify regions around the world where amphibian species may be at risk of chytrid infection. In high-risk areas, precautionary measures could be taken to prevent or control an introduction. These measures could include (1) close monitoring of the health of amphibians that are transported into and out of a high-risk area and (2) surveys within the high-risk area to check for the presence of Batrachochytrium dendrobatidis in streams or bodies of water. Control measures could be undertaken if B. dendrobatidis is identified (e.g. fungicide applications).

These results may suggest, for example, why chytridiomycosis has not been reported in certain locations. For instance, despite thorough testing, chytrid fungus has not been found on amphibian populations of the Southern High Plains (SHP) of the United States (M. San
Table 4. Two-proportions test and odds-ratio (OR) test for average summer maximum temperature. Comparisons of Types A and C and Types A and B. CI: upper and lower confidence limits

\begin{tabular}{|lrrrlcrr|}
\hline Site & $<30^{\circ} \mathrm{C}$ & $>30^{\circ} \mathrm{C}$ & Total & Site & $<30^{\circ} \mathrm{C}$ & $>30^{\circ} \mathrm{C}$ & Total \\
\hline Type A & 34 & 6 & 40 & Type A & 34 & 6 & 40 \\
Type C & 4 & 5 & 9 & Type B & 10 & 6 & 16 \\
Total & 38 & 11 & 49 & Total & 44 & 12 & 56 \\
\hline p-value & & 0.0084 & & & & 0.0638 & \\
OR & & 7.083 & & & 3.400 & $(1.110,10.410)$ \\
$90 \%$ CI & $(1.888,26.574)$ & & & & \\
\hline
\end{tabular}


Francsico \& L. Smith unpubl. data), even though several of the amphibian species of this region appear to be susceptible to chytrid infection (R. A. Rollins-Smith unpubl. data). Chytridiomycosis has been detected in amphibian species in several regions of the United States (e.g. Colorado, Sierra Nevada, California, and Arizona) (Daszak et al. 1999), and, therefore, Batrachochytrium dendrobatidis could have been introduced to the SHP (although this is unknown). However, based on the lack of observation of chytridiomycosis in amphibians on the SHP, it has been speculated that if $B$. dendrobatidis had been introduced to the SHP in the past, then it was unable to survive due to low rainfall and high summer temperatures. In addition, if $B$. dendrobatidis is introduced to the SHP in the future, this study indicates that the average summer maximum temperature of approximately $32^{\circ} \mathrm{C}$ on the SHP may be an important factor in limiting chytrid infection in amphibian populations for this region.

Acknowledgements. The authors are grateful to T. Halliday and J. Kauffman of the Declining Amphibian Population Task Force for providing an early version of the Declining Amphibian Database. We also thank L. Smith, Department of Range, Wildlife, \& Fisheries Management at Texas Tech University, M. San Francsico, Department of Biological Sciences at Texas Tech University, and R. A. Rollins-Smith, Department of Microbiology \& Immunology at Vanderbilt University Medical Center, for their comments on this research. In addition, we thank 3 referees for their suggestions on the original manuscript. This research was funded by the National Science Foundation, Grant DMS-0201105.

\section{LITERATURE CITED}

Alexander MA, Eischeid JK (2001) Climate variability in regions of amphibian declines. Conserv Biol 15:930-942

Berger L, Speare R, Daszak P, Green DE and 10 others (1998) Chytridiomycosis causes amphibian mortality associated with population declines in the rain forests of Australia and Central America. Proc Natl Acad Sci USA 95:9031-9036

Berger L, Speare R, Hyatt A (1999) Chytrid fungi and amphibian declines: overview, implications and future directions.

Editorial responsibility: Otto Kinne (Managing Editor), Oldendorf /Luhe, Germany
In: Campbell A (ed) Declines and disappearances of Australian frogs. Environment Australia, Canberra, p 21-31

Berger L, Speare R, Hines HB, Marantelli G and 10 others (2004) Effect of season and temperature on mortality in amphibians due to chytridiomycosis. Aust Vet J 82:31-36

Bosch J, Martínez-Solano I, García-París M (2001) Evidence of a chytrid fungus infection involved in the decline of the common midwife toad (Alytes obstetricans) in protected areas of central Spain. Biol Conserv 97:331-337

Collins JP, Brunner JL, Miera V, Parris MJ, Schock DM, Storfer A (2003) Ecology and evolution of infectious disease. In: Semlitsch RD (ed) Amphibian conservation. Smithsonian Institution, Washington, DC, p 137-151

Daszak P, Berger L, Cunningham AA, Hyatt AD, Green DE, Speare R (1999) Emerging infectious diseases and amphibian population declines. Emerg Infect Dis 5: 735-748

Daszak P, Cunningham AA, Hyatt AD (2003) Infectious disease and amphibian population declines. Divers Distrib 9: $141-150$

Dixon WJ, Massey Jr FJ (1969) Introduction to statistical analysis, 3rd edn. McGraw-Hill, New York

Drew A (2004) An investigation of climatic and geographic factors on the spread and growth of chytrid on amphibian populations in Australia. MS thesis, Texas Tech University, Lubbock, TX

Hosmer DW, Lemeshow S (1989) Applied logistic regression. John Wiley \& Sons, New York

Johnson ML, Berger L, Philips L, Speare R (2003) Fungicidal effects of chemical disinfectants, UV light, desiccation and heat on the amphibian chytrid Batrachochytrium dendrobatidis. Dis Aquat Org 57:255-260

Piotrowski JS, Annis SL, Longcore JF (2004) Physiology of Batrachochytrium dendrobatidis, a chytrid pathogen of amphibians. Mycologia 96:9-15

Retallick RWR, McCallum H, Speare R (2004) Endemic infection of the amphibian chytrid fungus in a frog community post-decline. PLoS (Public Library of Science) Biol 2: 1965-1971

Weldon CL, du Preez H, Hyatt AD, Muller R, Speare R (2004) Origin of the amphibian chytrid fungus. Emerg Infect Dis 10:2100-2105

Woodhams DC, Alford RA, Marantelli G (2003) Emerging diseases of amphibians cured by elevated body temperature. Dis Aquat Org 55:65-67

Young BE, Lips KR, Reaser JK, Ibanez R and 10 others (2001) Population declines and priorities for amphibian conservation in Latin America. Conserv Biol 15:1213-1223

Submitted: June 30, 2005; Accepted: November 28, 2005

Proofs received from author(s): February 9, 2006 